\title{
Alteration of $-656(\mathrm{G} / \mathrm{T})$ and $-607(\mathrm{C} / \mathrm{A})$ polymorphisms in interleukin-18 (IL-18) gene in house dust mite-sensitive allergic rhinitis patients in Thailand
}

\author{
A. Tungtrongchitr ${ }^{1}$, J. Jumpasri ${ }^{2}$, N. Sookrung ${ }^{3}$, N. Visitsunthorn ${ }^{4}$, \\ P. Tantilipikorn ${ }^{5}$, O. Piboonpocanan ${ }^{4}$, N. Indrawattana ${ }^{6}$, \\ R. Tungtrongchitr ${ }^{7}$ and W. Chaicumpa ${ }^{1}$
}

${ }^{1}$ Department of Parasitology, Faculty of Medicine, Siriraj Hospital, Mahidol University, Bangkok, Thailand ${ }^{2}$ Graduate Program in Microbiology, Department of Microbiology, Faculty of Medicine, Siriraj Hospital, Mahidol University, Bangkok, Thailand ${ }^{3}$ Office for Research and Development, Faculty of Medicine, Siriraj Hospital, Mahidol University, Bangkok, Thailand ${ }^{4}$ Department of Pediatrics, Faculty of Medicine, Siriraj Hospital, Mahidol University, Bangkok, Thailand ${ }^{5}$ Department of Otolaryngology, Faculty of Medicine, Siriraj Hospital, Mahidol University, Bangkok, Thailand ${ }^{6}$ Department of Microbiology and Immunology, Faculty of Tropical Medicine, Mahidol University, Bangkok, Thailand ${ }^{7}$ Department of Tropical Nutrition and Food Science,

Faculty of Tropical Medicine, Mahidol University, Bangkok, Thailand

Corresponding author: A. Tungtrongchitr

E-mail: anchalee.tun@mahidol.ac.th

Genet. Mol. Res. 16 (3): gmr16039641

Received February 8, 2017

Accepted March 27, 2017

Published July 6, 2017

DOI http://dx.doi.org/10.4238/gmr16039641

Copyright (C) 2017 The Authors. This is an open-access article distributed under the terms of the Creative Commons Attribution ShareAlike (CC BY-SA) 4.0 License.

ABSTRACT. Allergic rhinitis (AR) is an IgE-mediated inflammation of the nasal membranes, which is naturally triggered by aeroallergens. 
House dust mites (HDM) are the most common inhalant allergens. Interleukin-18 (IL-18) has been established as an essential cytokine that can activate the generation of IgE. This randomized controlled study aimed to identify the possible relationship of the genetic variations in the $I L-18$ gene with AR in mite-sensitive Thai patients. Study subjects consisted of 150 AR patients and 50 normal participants. Genomic DNA of 30 randomized AR patients and 30 randomized controls were screened by sequencing for the selection of candidate single nucleotide polymorphisms (SNPs), and further analyzed by polymerase chain reaction-restriction fragment length polymorphism (PCR-RFLP) assay for all subjects. The following five SNPs were detected in the $I L-18$ gene: $-656 \mathrm{G} / \mathrm{T},-607 \mathrm{C} / \mathrm{A}$, and $-137 \mathrm{G} / \mathrm{C}$ in promoter 1 and $-920 \mathrm{C} / \mathrm{T}$ and $-373 \mathrm{C} / \mathrm{G}$ in promoter 2 . The results showed that $-656 \mathrm{G} / \mathrm{T}$ and $-607 \mathrm{C} / \mathrm{A}$ SNPs were significantly correlated with $\mathrm{IgE}$ levels specific to Dermatophagoides pteronyssinus (Der $\mathrm{p}$ ) allergen $(\mathrm{P}=0.045$ and $\mathrm{P}$ $=0.045$, respectively), and significant differences were observed in the genotype distribution of AR patients when compared with controls [P $=0.044$ and $\mathrm{P}=0.044$, respectively; odds ratios $(\mathrm{ORs}): 1.941(95 \% \mathrm{CI}$, 1.014-3.715) and 1.941 (95\%CI, 1.014-3.715), respectively]. Our findings indicate that the $I L-18$ alleles, -656T (rs1946519) and -607A (rs1946518), might be associated with the higher production of Der $\mathrm{p}$ allergen-specific IgE in mite-sensitive AR patients.

Key words: Interleukin-18 (IL-18); Single nucleotide polymorphisms; Allergic rhinitis; House dust mite; Thai

\section{INTRODUCTION}

Allergic rhinitis (AR) is an IgE-mediated inflammation of the nasal mucosa, which is characterized by rhinorrhoea, sneezing, nasal congestion, and nasal pruritus. Currently, AR is considered the most common allergic disease, affecting 9 to $42 \%$ of the world population (Settipane and Charnock, 2007). In Thailand, the prevalence of AR has been estimated to be as high as $25 \%$ (Bunnag et al., 2009). Hypersensitivity to HDM allergen was found to be 60 $80 \%$ among the allergic Thai population (Kongpanichkul, et al., 1997; Bunnag, et al., 2000).

Allergy is caused by an interaction of the genetic and environmental factors (Jenerowicz et al., 2012). Indoor allergens derived mostly from house dust mites, cockroaches, cats, and dogs are the predominant cause of allergic stimulation in atopic patients (Salo et al., 2008; Pawankar et al., 2011). House dust mites (HDM), Dermatophagoides pteronyssinus $(D p)$ and $D$. farinae $(D f)$, are regarded as the major sources of indoor allergens (Platts-Mills, 2007). In predisposed individuals, the initial exposure to HDM allergen leads to an activation of the allergen-specific $\mathrm{T}$ helper $2\left(\mathrm{~T}_{\mathrm{H}} 2\right)$ cells and $\mathrm{IgE}$ synthesis called allergic sensitization. After the re-encounter of allergen, IgE cross-linking leads to the degranulation of mast cells and development of typical allergic symptoms.

Although extensive research has been conducted on the influence of genetics in asthma and atopic diseases, genetic involvement in AR has garnered far less attention. Most studies that have investigated AR in Asian populations were conducted in Japan, Korea, and

Genetics and Molecular Research 16 (3): gmr16039641 
Singapore; however, no study has been reported from Thailand. It has been postulated that AR is regulated by $\mathrm{T}_{\mathrm{H}} 2$ cells (Dávila et al., 2009). A number of genetic studies of single nucleotide polymorphisms (SNPs) involving genes encoding molecules that cause AR have been grouped as chemokines or their receptors, interleukin or their receptors, leukotrienes, and eosinophils (Dávila et al., 2009). The SNPs of $\mathrm{T}_{\mathrm{H}}$ 2-cell cytokines, such as interleukin IL-4, IL-5, IL-13, and IL-18 are reported to have associations with asthma and AR (Risma et al., 2002; Moissidis et al., 2005). In recent years, there has been an increased interest in the role of IL-18, given its capability of having both anti-allergic and allergy-promoting effects (Nakanishi et al., 2001). This cytokine is also known to influence the balance of $\mathrm{T}_{\mathrm{H}} 1 / \mathrm{T}_{\mathrm{H}} 2$ immune response (Izakovicova Holla, 2003) and allergic inflammatory reactions by upregulating IgE production, as well as inducing $\mathrm{Th}_{2}$ cytokine secretion, such as IL-4 and IL-13 (Tanaka et al., 2001). Atopic patients with exacerbation of asthma, atopic dermatitis, and AR have exhibited rising levels of IL-18, either in the serum or nasal secretions (Wong et al., 2001; Verhaeghe et al., 2002; Yoshizawa et al., 2002). Taken together, these aforementioned findings suggest that a genetic variant of the $I L-18$ gene might have an effect on $\mathrm{T}_{\mathrm{H}} 2$ function by elevating the production of allergenspecific IgE. In addition, some previous studies found SNPs in IL-18 promoter regions -656G, $-137 \mathrm{C}, 113 \mathrm{G}, 127 \mathrm{~T},-133 \mathrm{G}$, and $-607 \mathrm{~A} / \mathrm{C}$ to be associated with AR (Kruse et al., 2003; Lee et al., 2006). Accordingly, the aim of this study was to investigate the association between the following SNPs in the $I L-18$ gene that might influence the allergen-specific IgE levels against D. pteronyssinus and AR in Thai patients:

\section{MATERIAL AND METHODS}

\section{Study population}

This randomized controlled study was conducted at Siriraj Hospital from June 2012 to June 2013. Siriraj Hospital is Thailand's largest national tertiary referral center. This study consisted of two groups - the allergic rhinitis (AR) group (study group) and the control group. The inclusion criteria for AR patient group were the subjects, who were definitively diagnosed with AR according to the Allergic Rhinitis and its Impact on Asthma (ARIA) guidelines with a positive skin prick test for $D$. pteronyssinus. While the subjects in the control group were healthy volunteers without any chronic diseases that had negative skin prick test for HDM. Selected study group participants were of either gender, at least 18 years old, and had attended the Allergy Clinic at the Department of Pediatrics or the Department of Otolaryngology, Faculty of Medicine, Siriraj Hospital, Mahidol University. The participants in both groups, who had not been tested for skin prick test and the patients who took antihistamine drugs within seven days before blood collection, were excluded from the project.

Five milliliters of venous blood sample was obtained from each individual subject and treated with EDTA. Each sample was processed immediately to separate plasma and harvest leukocytes. Subsequently, both parts of the samples were individually stored at $-80^{\circ} \mathrm{C}$ until use. The IgE levels specific to D. pteronyssinus allergen in plasma samples were analyzed using ImmunoCAP ${ }^{\circledR} 100 \mathrm{E}$ automated system (Phadia Laboratory Systems, Uppsala, Sweden). The cutoff point between the CAP-positive and CAP-negative samples was $0.35 \mathrm{KAU} / \mathrm{L}$. A written informed consent was obtained from all subjects prior to their inclusion in the study. The protocol for this study was approved by the Siriraj Institutional Review Board (SIRB), Faculty of Medicine, Siriraj Hospital, Mahidol University, Bangkok, Thailand (Si 583/2011).

Genetics and Molecular Research 16 (3): gmr16039641 


\section{DNA extraction}

Three hundred microliter of the harvested leukocyte sample was used for genomic DNA extraction using a FlexiGene DNA Kit (Qiagen, Hilden, Germany) according to the manufacturer's guide. DNA concentration was measured using the NanoDrop 2000 Spectrophotometer (Thermo Fisher Scientific, Inc., Waltham, MA, USA). Purified DNA was stored at $-80^{\circ} \mathrm{C}$ under slightly basic conditions (Tris- $\mathrm{Cl}, \mathrm{pH}$ 8.0). A polymerase chain reaction (PCR) was optimized for $200 \mathrm{ng}$ of DNA. The selected primer pairs are shown in Table 1.

\begin{tabular}{|c|c|c|}
\hline Region & Primer & Annealing temperature $\left({ }^{\circ} \mathrm{C}\right)$ \\
\hline \multirow{2}{*}{ Promoter 1} & F: 5'-TAACATGTTGAACATAAGCCCTA-3' & \multirow[t]{2}{*}{66} \\
\hline & R: 5'-GGTGGCAGCCGCTTTAGCAGCTAG-3' & \\
\hline \multirow[t]{14}{*}{ Promoter 2 (from -2470 to Exon 2) } & F: 5'-GATTCTTCTCTCCCACTAGAC-3' & \multirow[t]{2}{*}{56} \\
\hline & R: 5'-CATTTGAGCTCAGGAGTTTGAG-3' & \\
\hline & F: 5'-AGAACTTTGAGAGGCCAAGT-3' & \multirow[t]{2}{*}{60} \\
\hline & R: 5'-TGTATAATTTTGGCCTCCCAA-3' & \\
\hline & F: 5'-GAGCATAAGGAACTAAACCTAG-3' & \multirow[t]{2}{*}{58} \\
\hline & R: 5'-GACAGAGTCACAAGTACTAC-3' & \\
\hline & F: 5'-TGTCTCAAGATCTCTGCAATA-3' & \multirow[t]{2}{*}{56} \\
\hline & R: 5'-ATCAAGGGATACAGGATTTGA-3' & \\
\hline & F: 5'-TGCACACCGTATTGGAAGAGG-3' & \multirow[t]{2}{*}{56} \\
\hline & R: 5'-CTTCTCTTACAACCAGTGGGT-3' & \\
\hline & F: 5'-GACAATGAAGTCACAAACCTTC-3' & \multirow[t]{2}{*}{56} \\
\hline & R: 5'-TCAGCTTATGAATACCCATGT-3' & \\
\hline & F: 5'-GTTCAGTACTAGGCCATTTATC-3' & \multirow[t]{2}{*}{56} \\
\hline & R: 5'-TGTTCTATGGCATTAGCCTTAC-3' & \\
\hline
\end{tabular}

\section{Direct sequencing}

Thirty randomized AR patients and 30 randomized control subjects were screened by sequencing for the selection of candidate SNPs in promoters 1 and 2 of the $I L-18$ gene. The genomic DNA of each region was amplified by PCR using the appropriate primers (Table 1). For promoter 1 , the PCR was performed in a $25-\mu \mathrm{L}$ reaction mixture containing 150 ng genomic DNA, $300 \mu \mathrm{M}$ dNTP, $2.0 \mathrm{mM} \mathrm{MgCl}, 0.5 \mathrm{U}$ HotStart DNA polymerase (Kapa Biosystems, Inc., Wilmington, MA, USA), and $0.3 \mu \mathrm{M}$ each primer. The PCR amplification was performed using the following reaction conditions: initial denaturation at $95^{\circ} \mathrm{C}$ for 5 min, followed by 25 cycles of denaturation at $98^{\circ} \mathrm{C}$ for $20 \mathrm{~s}$, annealing at $66^{\circ} \mathrm{C}$ for $15 \mathrm{~s}$, and extension at $72^{\circ} \mathrm{C}$ for $20 \mathrm{~s}$, followed by a final extension step at $72^{\circ} \mathrm{C}$ for $5 \mathrm{~min}$. For promoter 2 , the PCR was performed in a $25-\mu \mathrm{L}$ reaction volume consisting of 150 ng genomic DNA, $200 \mu \mathrm{M}$ dNTP, $1.5 \mathrm{mM} \mathrm{MgCl}$, 1.5 U Taq DNA polymerase (Thermo Fisher Scientific, Inc., Waltham, MA, USA), and $0.32 \mu \mathrm{M}$ each primer. The PCR amplification was performed using the following reaction conditions: initial denaturation at $95^{\circ} \mathrm{C}$ for $10 \mathrm{~min}$, followed by 30 cycles of denaturation at $95^{\circ} \mathrm{C}$ for $1 \mathrm{~min}$, annealing at primer-specific temperatures for $45 \mathrm{~s}$ (Table 1), and extension at $72^{\circ} \mathrm{C}$ for $45 \mathrm{~s}$, followed by a final extension step at $72^{\circ} \mathrm{C}$ for 10 min. Detection of SNPs was confirmed by oligonucleotide sequencing (DNA sequencing) and comparison with sequences in the National Center for Biotechnology Information (NCBI) GenBank database (NCBI Reference Sequence: NG_028143.1).

\section{PCR-restriction fragment length polymorphism (PCR-RFLP)}

Genotyping of $-656(\mathrm{G} / \mathrm{T})$ and $-607(\mathrm{C} / \mathrm{A})$ polymorphisms was performed using the

Genetics and Molecular Research 16 (3): gmr16039641 
PCR-RFLP technique. PCR for -656(G/T) genotyping was performed with mutated primers, introducing a restriction site for RFLP analysis of the respective genotype (Table 2). PCR was performed in a $25-\mu \mathrm{L}$ reaction mixture comprising $150 \mathrm{ng}$ DNA, $200 \mu \mathrm{M}$ dNTP, $1.5 \mathrm{mM}$ $\mathrm{MgCl}_{2}, 1.5 \mathrm{U}$ Taq DNA polymerase (Thermo Fisher Scientific, Inc., Waltham, MA, USA), and $0.32 \mu \mathrm{M}$ each primer. The amplification was performed using the following reaction conditions: initial denaturation at $95^{\circ} \mathrm{C}$ for $5 \mathrm{~min}$, followed by 30 cycles denaturation at $95^{\circ} \mathrm{C}$ for $1 \mathrm{~min}$, annealing at primer-specific temperatures for $45 \mathrm{~s}$ (Table 2), and extension at $72^{\circ} \mathrm{C}$ for $45 \mathrm{~s}$, followed by a final extension step at $72^{\circ} \mathrm{C}$ for $6 \mathrm{~min}$. The amplified product was digested with enzyme HpyF10 VI (Thermo Fisher Scientific). For determination of -656(G/T) polymorphism, the PCR product of the 120-bp DNA segment was digested with HpyF10 VI (Thermo Fisher Scientific), and the amplicon of the 301-bp DNA segment was digested with Tru1I (Thermo Fisher Scientific) to verify $-607(\mathrm{C} / \mathrm{A})$ polymorphism. Each digested DNA preparation was subjected to $4 \%$ agarose gel electrophoresis followed by ethidium bromide staining. The electrophoresis results were visualized and recorded using a Gel Doc 2000 gel documentation system (Bio-Rad Laboratories, Inc., Hercules, CA, USA). A Fermentas GeneRuler Low Range DNA Ladder (Thermo Fisher Scientific) was used as a DNA size marker in each gel slab.

Table 2. Primer for restriction fragment length polymorphism analysis.

\begin{tabular}{l|l|c|l}
\hline Polymorphism & Primer & Annealing temperature $\left({ }^{\circ} \mathrm{C}\right)$ & Enzyme \\
\hline \multirow{2}{*}{ Promoter 1, -656 } & F: 5'-AGGTCAGTCTTTGCTATCATTCCAGG-3' & 58 & HpyF10 VI \\
\cline { 2 - 2 } & R: 5'-CTGCAACAGAAAGTAAGCTTGCGGAGAGG-3' & & \\
\hline \multirow{2}{*}{ Promoter 1, -607 } & F: 5'-CTTTGCTATCATTCCAGGAA-3' & 54 & Tru1I \\
\cline { 2 - 2 } & R: 5'-TAACCTCATTCAGGACTTCC-3' & & \\
\hline
\end{tabular}

\section{Statistical analysis}

Data analysis was performed using the software SPSS for Windows version 16.0 (SPSS, Inc., Chicago, IL, USA). Results are presented as numbers and percentages or means \pm standard deviations (SD). All SNPs were checked for conformation with HardyWeinberg expectations (HWE) using Michael H. Court's (2005-2008) online calculator (http:// scienceprimer.com/hardy-weinberg-equilibrium-calculator) (Wigginton et al., 2005). The Mann-Whitney U test was used to compare the wild-type and variant genotype frequencies with allergen-specific IgE. The comparison of the allele and genotype frequencies and the association between polymorphisms and AR patients and control subjects were examined for statistical significance using the Pearson chi-square test or Fisher exact test. Odds ratios (ORs) with 95\% confidence intervals (CIs) were calculated to assess the relative disease risk conferred by a specific allele. A P value $<0.05$ was considered statistically significant.

\section{RESULTS}

One hundred and fifty AR patients (61 men and 89 women) and 50 control subjects (14 men and 36 women) were recruited and genotyped for $I L-18$ polymorphisms. Demographic and clinical data of the study population are shown in Table 3 . The mean ages of AR patients and control subjects were $31.93 \pm 12.42$ and $26.34 \pm 6.52$, respectively. The gender ratio (male:female) of control subjects (1:2.57) was higher than that of AR patients (1:1.46). The

Genetics and Molecular Research 16 (3): gmr16039641 
mean specific IgE level of the AR patient group $(15.72 \pm 26.59)$ was significantly higher than that of the control group $(0.11 \pm 0.13)$.

Table 3. Characteristics of the study population.

\begin{tabular}{l|c|c}
\hline Characteristic & Control subjects $[\mathrm{N}=50(\%)]$ & AR subjects [N=150 (\%)] \\
\hline Age $(\mathrm{yr} ;$ mean $\pm \mathrm{SD})$ & $26.34 \pm 6.52$ & $31.93 \pm 12.42$ \\
\hline Gender & & $61(40.7 \%)$ \\
\hline Male $(\mathrm{N}, \%)$ & $14(28 \%)$ & $89(59.3 \%)$ \\
\hline Female $(\mathrm{N}, \%)$ & $36(72 \%)$ & $15.72 \pm 26.59$ \\
\hline Specific IgE to Der $p$ allergen $($ KUA/L; mean $\pm \mathrm{SD})$ & $0.11 \pm 0.13$ & \\
\hline
\end{tabular}

The allele frequencies of AR and control subjects are shown in Table 4. In genotype analysis, all SNPs had no deviation from HWE (P value $>0.05$ ). No statistically significant difference was observed in the genotype polymorphisms between the AR and control groups at all studied positions of the human $I L-18$ gene (-656, -607, and -137 in promoter 1 ; and, -920 and -373 in promoter 2). However, among the analyzed SNPs, the genetic variations in -656 and -607 were likely to correlate with AR or IgE production in patients. Consequently, the polymorphisms -656 and -607 were selected for further study by PCR-RFLP.

Table 4. The genotype of polymorphisms in promoter regions in the human $I L-18$ gene.

\begin{tabular}{|c|c|c|c|c|c|}
\hline Allele position & AR group [N (\%)] & MAF & Control group [N (\%)] & MAF & $P$ value \\
\hline \multicolumn{6}{|l|}{ Promoter 1} \\
\hline \multicolumn{6}{|l|}{-656} \\
\hline GG & $8(26.7)$ & \multirow[t]{3}{*}{$\mathrm{T}=0.48$} & $13(43.3)$ & \multirow[t]{3}{*}{$\mathrm{T}=0.35$} & \multirow[t]{3}{*}{0.383} \\
\hline GT & $15(50)$ & & $13(43.3)$ & & \\
\hline TT & $7(23.3)$ & & $4(13.3)$ & & \\
\hline \multicolumn{6}{|l|}{-607} \\
\hline $\mathrm{CC}$ & $8(26.7)$ & \multirow[t]{3}{*}{$\mathrm{A}=0.48$} & $13(43.3)$ & \multirow[t]{3}{*}{$\mathrm{A}=0.37$} & \multirow[t]{3}{*}{0.402} \\
\hline $\mathrm{CA}$ & $15(50)$ & & $12(40)$ & & \\
\hline $\mathrm{AA}$ & $7(23.3)$ & & $5(16.7)$ & & \\
\hline \multicolumn{6}{|l|}{-137} \\
\hline GG & $22(73.3)$ & \multirow[t]{3}{*}{$\mathrm{C}=0.15$} & $24(80)$ & \multirow[t]{3}{*}{$\mathrm{C}=0.12$} & \multirow[t]{3}{*}{0.871} \\
\hline $\mathrm{GC}$ & $7(23.3)$ & & $5(16.7)$ & & \\
\hline $\mathrm{CC}$ & $1(3.3)$ & & $1(3.3)$ & & \\
\hline \multicolumn{6}{|l|}{ Promoter 2} \\
\hline \multicolumn{6}{|l|}{-920} \\
\hline TT & $13(43.3)$ & \multirow[t]{3}{*}{$\mathrm{C}=0.33$} & $18(60)$ & \multirow[t]{3}{*}{$\mathrm{C}=0.25$} & \multirow[t]{3}{*}{0.419} \\
\hline TC & $14(46.7)$ & & $9(30)$ & & \\
\hline $\mathrm{CC}$ & $3(10)$ & & $3(10)$ & & \\
\hline \multicolumn{6}{|l|}{-373} \\
\hline $\mathrm{CC}$ & $14(46.7)$ & \multirow[t]{3}{*}{$\mathrm{G}=0.32$} & $18(60)$ & \multirow[t]{3}{*}{$\mathrm{G}=0.25$} & \multirow[t]{3}{*}{0.605} \\
\hline $\mathrm{CG}$ & $13(43.3)$ & & $9(30)$ & & \\
\hline GG & $3(10)$ & & $3(10)$ & & \\
\hline \multicolumn{6}{|l|}{-133} \\
\hline $\mathrm{CC}$ & $22(73.3)$ & \multirow[t]{3}{*}{$\mathrm{G}=0.15$} & $25(83.3)$ & \multirow[t]{3}{*}{$\mathrm{G}=0.08$} & \multirow[t]{3}{*}{0.532} \\
\hline $\mathrm{CG}$ & $7(23.3)$ & & $5(16.7)$ & & \\
\hline GG & $1(3.3)$ & & 0 & & \\
\hline
\end{tabular}

MAF; minor allele frequency, $\mathrm{P}$ value; compared the genotypes distribution between groups.

For $-656 \mathrm{G} / \mathrm{T}$, the DNA restriction fragment from TT homozygous individuals was 120 -bp fragments, whereas the $H p y \mathrm{~F} 10$ VI enzyme cut DNA from GG homozygous individuals into 96- and 24-bp fragments. DNA from GT heterozygous individuals showed the expected fragments at 120, 96, and $24 \mathrm{bp}$ (Figure 1).

Genetics and Molecular Research 16 (3): gmr16039641 


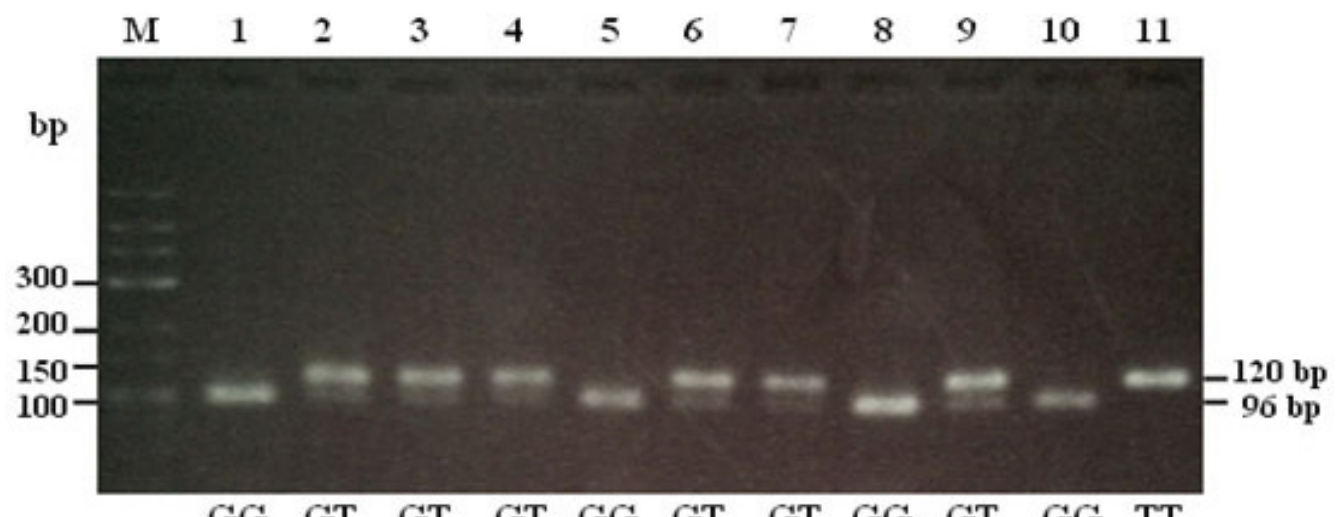

Figure 1. Genotyping of $-656(\mathrm{G} / \mathrm{T})$ polymorphism by PCR-RFLP. Size markers are shown in lane M; GG homozygous genotypes are in lanes 1, 5,8, and 10; GT heterozygous genotypes in lanes 2, 3, 4, 6, 7, and 9; and TT homozygous genotypes in lane 11 .

For -607C/A, DNA from CC homozygous individuals was cut into 199-, 72-, and 30bp fragments, whereas Tru1I enzyme cut DNA from AA homozygous individuals into 101-, 98-, 72-, and 30-bp fragments. DNA from CA heterozygous individuals showed the expected fragments at 199, 101, 98, 72, and $30 \mathrm{bp}$ (Figure 2).

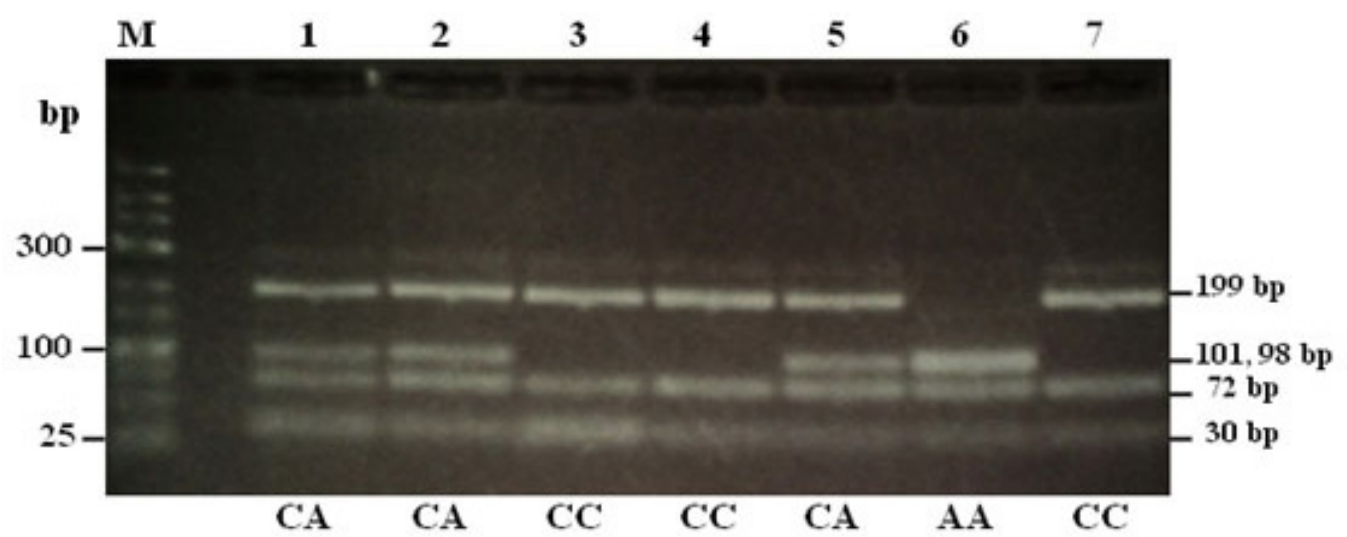

Figure 2. Genotyping of $-607(\mathrm{C} / \mathrm{A})$ polymorphism by PCR-RFLP. Size markers are shown in lane M; CC homozygous genotypes are in lanes 3, 4, and 7; CA heterozygous genotypes in lanes 1,2, and 5; and AA homozygous genotypes in lane 6 .

No linkage disequilibrium was observed between the -656 and -607 SNPs in the $I L-18$ gene. Correlations between Der $\mathrm{p}$ allergen-specific IgE levels and variant genotype of SNPs -656 and -607 in the $I L-18$ gene $(\mathrm{P}=0.04$ for both) are shown in Table 5. Genotype and allele frequency distributions of -656 and -607 polymorphisms in the $I L-18$ gene are summarized in Table 6 . The median specific IgE level was significantly different between the wild-type and variant genotypes $(\mathrm{P}=0.045)$. The -656 and -607 variant genotypes were found to be significantly associated with allergic rhinitis $(\mathrm{P}=0.044)$. 
Table 5. The association of the level of Der p allergen-specific IgE with variant genotypes in the $I L-18$ gene.

\begin{tabular}{l|c|c|c|c}
\hline Der p allergen-specific IgE & Variant & Genotype & Total [N $=200(\%)]$ & P value \\
\hline & $-656(\mathrm{G} / \mathrm{T})$ & GG & $76(38 \%)$ & \\
\hline & & GT + TT & $124(62 \%)$ & 0.04 \\
\hline & $-607(\mathrm{C} / \mathrm{A})$ & CC & $76(38 \%)$ & 0.04 \\
\hline
\end{tabular}

Table 6. Comparison of genotype and allele frequencies distributions of -656 and -607 polymorphisms in the $I L-18$ gene in allergic rhinitis (AR) and control groups.

\begin{tabular}{|c|c|c|c|c|c|c|}
\hline Variants & Genotype/Alleles & $\begin{array}{c}\text { AR groups } \\
\text { N (\%) }\end{array}$ & $\begin{array}{c}\text { Control groups } \\
\mathrm{N}(\%)\end{array}$ & OR & $95 \% \mathrm{CI}$ & P value \\
\hline \multirow{4}{*}{$-656(\mathrm{G} / \mathrm{T})$} & GG & $51(33.9)$ & $25(50 \%)$ & \multirow{4}{*}{1.941} & \multirow[t]{4}{*}{$1.014-3.715$} & \multirow{4}{*}{0.04} \\
\hline & GT + TT & $99(66.1)$ & $25(50 \%)$ & & & \\
\hline & $\mathrm{G}$ & $177(59)$ & $70(70 \%)$ & & & \\
\hline & $\mathrm{T}$ & $123(41)$ & $30(30 \%)$ & & & \\
\hline \multirow[t]{4}{*}{$-607(\mathrm{C} / \mathrm{A})$} & $\mathrm{CC}$ & $51(33.9)$ & $25(50 \%)$ & \multirow[t]{4}{*}{1.941} & \multirow[t]{4}{*}{$1.014-3.715$} & \multirow[t]{4}{*}{0.04} \\
\hline & $\mathrm{CA}+\mathrm{AA}$ & $99(66.1)$ & $25(50)$ & & & \\
\hline & $\mathrm{C}$ & $176(58.669)$ & $69(69)$ & & & \\
\hline & A & $123(41.33)$ & $31(31)$ & & & \\
\hline
\end{tabular}

\section{DISCUSSION}

Human interleukin-18 (IL-18) was formerly referred to as interferon- $\gamma$ (IFN- $\gamma$ )inducing factor because it controls the production of interferon (IFN)- $\gamma$. IL-18 regulates both innate and acquired immune responses, as well as T-cell differentiation. Major sources of IL18 are macrophages and dendritic cells. It has been established that the serum IL-18 levels in AR patients (Verhaeghe et al., 2002), allergic asthma (Wong et al., 2001), and atopic dermatitis (Yoshizawa et al., 2002) were higher than those in the normal controls. These findings suggest the suitability of the $I L-18$ gene as an excellent candidate gene for further studies relative to its involvement in AR (Koppelman et al., 2002) and mite sensitization (Kurz et al., 2000). Various SNPs of $I L-18$ have been reported to be associated with AR in different races from different parts of the world (Verhaeghe et al., 2002; Kruse et al., 2003; Moissidis et al., 2005; Lee et al., 2006; Sebelova et al., 2007; Dávila et al., 2009); however, no studies have been conducted in the Thai population yet. In the current study, we set forth to investigate the association between SNPs in $I L-18$ that might influence allergen-specific IgE levels to $D$. pteronyssinus and AR in Thai patients.

Our investigation focused mainly on the mite-sensitive subjects as $60-80 \%$ of the Thai atopic patients are allergic to this allergen and mites are considered the most common allergen in Thailand. A promoter of $I L-18$ is a fragment of DNA that specifically instructs its transcription. A mutation in the sequence of a promoter, transcription factor, or transcription co-activator might influence its function or protein synthesis, which is proposed to be the etiology of various diseases, including allergy. We, therefore, set forth to explore the variation in both promoters of the $I L-18$ gene. Polymorphisms in promoter regions would disturb the protein sequence of IL-18 and its production, which in turn, could affect IgE synthesis and lead to the development of allergic diseases. Conversely, mutations might not influence its protein sequence, but could cause changes in its production. Collectively, these changes result in immune responses that are mediated by IL-18 and that might be linked with a range of immunologic diseases. Our previous findings also demonstrated that IL-18/IL-133

Genetics and Molecular Research 16 (3): gmr16039641 
polymorphism was significantly associated with Der $\mathrm{p}$ allergen-specific $\operatorname{IgE}$ in $\mathrm{AR}(\mathrm{P}=0.025)$, but not in allergic phenotypes. (Jumpasri et al., 2014).

The expression of $I L-18$ is regulated by two TATA-less promoters; one upstream of the untranslated exon 1 and the other upstream of exon 2 (in intron 1) (Tone et al., 1997). The lipopolysaccharide (LPS) is able to induce the upstream promoter, and the downstream promoter demonstrates constitutive activity (Kim et al., 1999). It has been documented that the activated macrophages and T-cells were upregulated by promoter 1 of $I L-18$, whereas the activity of promoter 2 was constitutively noticeable (Tone et al., 1997). The SNPs detected in promoter $1(-137 \mathrm{C})$, exon 1 (113G and $127 \mathrm{~T})$, and promoter $2(-133 \mathrm{G})$ showed strong association with atopic phenotypes. These SNPs were significantly associated with high IgE levels ( $\mathrm{P} \leq .005$; OR, 3.27-3.96 (Kruse et al., 2003). These findings suggested that mutations in both promoters would involve allergic diseases. We, therefore, started by attempting to identify candidate SNPs in promoter 1 and 2 of $I L-18$ by direct sequencing of 30 AR cases versus 30 normal controls. We found that SNPs -656 and -607 showed a higher tendency to correlate with AR than the other evaluated SNPs (Table 4). Accordingly, these two SNPs were selected as the candidate SNPs for further study in all subjects by PCR-RFLP.

Although these polymorphisms were reported to be related to the allergic phenotypes, conflicting results regarding their relation to different allergic diseases were found in the literature. Correlation of $I L-18$ variants with AD was reported in a German population (Kurz et al., 2000; Kruse et al., 2003). Association with asthma was detected in South Korea (Shin et al., 2005) and in white populations (Kurz et al., 2000). Conversely, a study in atopic Czech patients showed negative association with $I L-18$ variants (Sebelova et al., 2007; Izakovicova Holla et al., 2010). These findings suggest that the phenotypic results of the $I L-18$ promoter polymorphism might vary by both environment and ethnicity. Moreover, the association of genetic variation with the severity of allergic diseases has been noted in the Egyptian and Korean patients (Shin et al., 2005; Imboden et al., 2006; Ibrahim et al., 2012). Our results showed that the median-specific IgE level of the wild-type genotypes was significantly different from that of the variant genotypes for both -656 and -607 SNPs $(\mathrm{P}=0.045)$. IL-18 is known to influence the balance of Th1/Th2 immune response (Lee et al., 2006). This cytokine is involved in the allergic inflammatory reactions by indirectly inducing B-cell isotype by switching to $\operatorname{IgE}$ and inducing the production of Th2 cytokines, such as IL-4 and IL-13 (Nakanishi et al., 2001; Risma et al., 2002; Moissidis et al., 2005). A higher amount of IL-4 and less IFN-gamma was detected in the mite-specific clones from the subjects with high levels of allergen-specific IgE than in those from the patients with low levels of allergen-specific IgE. The production of IL-4 is relevant to the synthesis of mite allergen-specific IgE. These results suggest that IL-18 and T-cell receptor-mediated stimulation with allergens, such as house dust mites, would stimulate IgE production. IL-18 polymorphisms at the -656 and -607 positions would reflect upregulated IgE production.

A number of studies have established the association of AR with other cytokines and genes such as IL-6 (Zhao et al., 2016); IL-10 and TGF- $\beta$ polymorphisms (Nasiri et al., 2016); IL-12B (Wei et al., 2016); IL33/IL1RL1, IL-13-RAD50 and C11orf30/LRRC32 (Li et al., 2015); JAK1 gene polymorphisms (Shen et al., 2016). In contrast, Henmyr et al. (2016) found no associations between the genetic variation in TLR8 and AR. Moreover, a study on a North Indian population showed that the IL-18 $-137 \mathrm{G} / \mathrm{C}$ polymorphism conferred a significant protection from asthma. (Birbian et al., 2013).

The -656 and -607 variant genotypes were found to be significantly associated with AR in Thai patients $(\mathrm{P}=0.044)$. Eight common SNPs in the $I L-18$ promoter region were 
reported in a German population, and among those, five SNPs (656G, 137C, 113G, 127T, 133G) were associated with AR (Kruse et al., 2003). Our finding is relevant to that report, but only for the IL-18/-656 SNP. The IL-18/-607 SNP was found to have no association with AR in that study, which contrasts with the results of the present study. The allele A at -607 in the $I L-18$ gene was found to be related to the development of AR in a Korean population, which corresponds with our result (Lee et al., 2006). Due to the fact that polymorphism is functional, the susceptibility to common disorders among different populations appears to differ as a result of ethnic differences and environmental influences. Moreover, alterations in exposure to specific environmental factors might lead to the expression of atopic phenotypes in the previously unaffected genetically susceptible individuals. By determining the significance of a polymorphism in a candidate gene in an allergic disease, it might be possible to predict the susceptibility of a particular individual to that disease. The early detection of individuals at risk for allergic diseases would facilitate the improvement of existing health measures and the development of new preventive public health measures. Moreover, the knowledge gained from the investigations similar to the present study would be directly applicable to the development of new therapeutic strategies.

Further studies should investigate the association between -656 and -607 SNPs and other allergic diseases in Thais, such as atopic dermatitis and asthma. We should also endeavor to study the potential effect of the -656 and -607 SNPs on the expression of the $I L-18$ gene, cytokine function, and serum levels of IL-18.

To the best of our knowledge, this study is the first to explore the association between $I L-18$ gene polymorphisms and AR in Thai patients. Our findings demonstrated that $-656(\mathrm{G} /$ T) and $-607(\mathrm{C} / \mathrm{A})$ polymorphisms in $I L-18$ gene are significantly associated with AR in Thai population. Moreover, the -656 and -607 variant genotypes are associated with to Der p-specific IgE levels when compared with wild-type genotypes. Therefore, the analysis of the $I L-18$ gene might be useful to further investigate the allergic diseases, especially AR, in the Thai population in the future.

\section{Conflicts of interest}

The authors declare no conflict of interest.

\section{ACKNOWLEDGMENTS}

The authors thank all CR allergic patients for their participation in this study. The work was supported by the National Research University (NRU) project of the Office of Commission on Higher Education, Ministry of Education, Thailand through the Center of Biopharmaceutical Development and Innovative Therapy, Mahidol University and partially supported by the Faculty of Medicine, Siriraj Hospital, Mahidol University. Anchalee Tungtrongchitr and Nitat Sookrung were supported by a "Chalermphrakiat" Grant, Faculty of Medicine, Siriraj Hospital, Mahidol University. Nitat Sookrung and Nitaya Indrawattana are new research scholars of the TRF.

\section{REFERENCES}

Birbian N, Singh J and Jindal SK (2013). Protective role of IL-18 -137G/C polymorphism in a North Indian population with asthma: a pilot study. Cytokine 61: 188-193. http://dx.doi.org/10.1016/j.cyto.2012.09.015

Genetics and Molecular Research 16 (3): gmr16039641 
Bunnag C, Jareoncharsri P, Voraprayoon S and Kongpatanakul S (2000). Epidemiology of rhinitis in Thais: characteristics and risk factors. Asian Pac. J. Allergy Immunol. 18: 1-7.

Bunnag C, Jareoncharsri P, Tantilipikorn P, Vichyanond P, et al. (2009). Epidemiology and current status of allergic rhinitis and asthma in Thailand -- ARIA Asia-Pacific Workshop report. Asian Pac. J. Allergy Immunol. 27: 79-86.

Dávila I, Mullol J, Ferrer M, Bartra J, et al. (2009). Genetic aspects of allergic rhinitis. J. Investig. Allergol. Clin. Immunol. 19 (Suppl 1): 25-31.

Henmyr V, Lind-Halldén C, Carlberg D, Halldén C, et al. (2016). Characterization of genetic variation in TLR8 in relation to allergic rhinitis. Allergy 71: 333-341. http://dx.doi.org/10.1111/all.12805

Ibrahim GH, ElTabbakh MT, Gomaa AH and Mohamed EA (2012). Interleukin-18 gene polymorphisms in Egyptian patients with allergic diseases. Am. J. Rhinol. Allergy 26: 385-389. http://dx.doi.org/10.2500/ajra.2012.26.3806

Imboden M, Nicod L, Nieters A, Glaus E, et al.; SAPALDIA Team (2006). The common G-allele of interleukin-18 singlenucleotide polymorphism is a genetic risk factor for atopic asthma. The SAPALDIA Cohort Study. Clin. Exp. Allergy 36: 211-218. http://dx.doi.org/10.1111/j.1365-2222.2006.02424.x

Izakovicova Holla L (2003). Interleukin-18 in asthma and other allergies. Clin. Exp. Allergy 33: 1023-1025. http://dx.doi. org/10.1046/j.1365-2222.2003.01738.x

Izakovicova Holla L, Hrdlicková B, Schüller M, Buckova D, et al. (2010). Haplotype analysis of the interleukin-18 gene in Czech patients with allergic disorders. Hum. Immunol. 71: 592-597. http://dx.doi.org/10.1016/j.humimm.2010.03.004

Jenerowicz D, Silny W, Dańczak-Pazdrowska A, Polańska A, et al. (2012). Environmental factors and allergic diseases. Ann. Agric. Environ. Med. 19: 475-481.

Jumpasri J, Tungtrongchitr A, Sookrung N, Tantilipikorn P, et al. (2014). Association of interleukin 18 (IL-18)/-133(C/G) polymorphism with specific IgE levels to Der $p$ allergens in Thai allergic rhinitis patients. Proceedings of the 15 th Graduate Research Conference, Graduate School, Khon Kaen University, Thailand.

Kim YM, Kang HS, Paik SG, Pyun KH, et al. (1999). Roles of IFN consensus sequence binding protein and PU.1 in regulating IL-18 gene expression. J. Immunol. 163: 2000-2007.

Kongpanichkul A, Vichyanond P and Tuchinda M (1997). Allergen skin test reactivities among asthmatic Thai children. J. Med. Assoc. Thai. 80: 69-75.

Koppelman GH, Stine OC, Xu J, Howard TD, et al. (2002). Genome-wide search for atopy susceptibility genes in Dutch families with asthma. J. Allergy Clin. Immunol. 109: 498-506. http://dx.doi.org/10.1067/mai.2002.122235

Kruse S, Kuehr J, Moseler M, Kopp MV, et al. (2003). Polymorphisms in the IL 18 gene are associated with specific sensitization to common allergens and allergic rhinitis. J. Allergy Clin. Immunol. 111: 117-122. http://dx.doi. org $/ 10.1067 /$ mai.2003.43

Kurz T, Strauch K, Heinzmann A, Braun S, et al. (2000). A European study on the genetics of mite sensitization. J. Allergy Clin. Immunol. 106: 925-932. http://dx.doi.org/10.1067/mai.2000.110557

Lee HM, Park SA, Chung SW, Woo JS, et al. (2006). Interleukin-18/-607 gene polymorphism in allergic rhinitis. Int. J. Pediatr. Otorhinolaryngol. 70: 1085-1088. http://dx.doi.org/10.1016/j.ijporl.2005.11.006

Li J, Zhang Y and Zhang L (2015). Discovering susceptibility genes for allergic rhinitis and allergy using a genomewide association study strategy. Curr. Opin. Allergy Clin. Immunol. 15: 33-40. http://dx.doi.org/10.1097/ ACI.0000000000000124

Moissidis I, Chinoy B, Yanamandra K, Napper D, et al. (2005). Association of IL-13, RANTES, and leukotriene C4 synthase gene promoter polymorphisms with asthma and/or atopy in African Americans. Genet. Med. 7: 406-410. http://dx.doi.org/10.1097/01.GIM.0000170994.24960.48

Nakanishi K, Yoshimoto T, Tsutsui H and Okamura H (2001). Interleukin-18 regulates both Th1 and Th2 responses. Annu. Rev. Immunol. 19: 423-474. http://dx.doi.org/10.1146/annurev.immunol.19.1.423

Nasiri R, Hirbod-Mobarakeh A, Movahedi M, Farhadi E, et al. (2016). Gene polymorphisms of interleukin-10 and transforming growth factor beta in allergic rhinitis. Allergol. Immunopathol. (Madr.) 44: 125-130. http://dx.doi. org/10.1016/j.aller.2015.05.010

Pawankar R, Canonica GW, Holgate ST and Lockey RF (2011). World Allergy Organization (WAO) White book on allergy. Milwaukee (WI): World Allergy Organization. Available at [http://www.worldallergy.org].

Platts-Mills TA (2007). The role of indoor allergens in chronic allergic disease. J. Allergy Clin. Immunol. 119: 297-302. http://dx.doi.org/10.1016/j.jaci.2006.12.647

Risma KA, Wang N, Andrews RP, Cunningham CM, et al. (2002). V75R576 IL-4 receptor alpha is associated with allergic asthma and enhanced IL-4 receptor function. J. Immunol. 169: 1604-1610. http://dx.doi.org/10.4049/ jimmunol.169.3.1604

Sebelova S, Izakovicova-Holla L, Stejskalova A, Schüller M, et al. (2007). Interleukin-18 and its three gene polymorphisms relating to allergic rhinitis. J. Hum. Genet. 52: 152-158. http://dx.doi.org/10.1007/s10038-006-0093-2

Genetics and Molecular Research 16 (3): gmr16039641 
Settipane RA and Charnock DR (2007). Epidemiology of rhinitis: allergic and nonallergic. Clin. Allergy Immunol. 19: 23-34.

Shin HD, Kim LH, Park BL, Choi YH, et al. (2005). Association of interleukin 18 (IL18) polymorphisms with specific IgE levels to mite allergens among asthmatic patients. Allergy 60: 900-906. http://dx.doi.org/10.1111/j.13989995.2005.00619.x

Salo PM, Arbes SJ, Jr., Crockett PW, Thorne PS, et al. (2008). Exposure to multiple indoor allergens in US homes and its relationship to asthma. J. Allergy Clin. Immunol. 121: 678-684.e2. http://dx.doi.org/10.1016/j.jaci.2007.12.1164

Shen Y, Liu Y, Ke X, Kang HY, et al. (2016). Association between JAK1 gene polymorphisms and susceptibility to allergic rhinitis. Asian Pac. J. Allergy Immunol. 34: 124-129.

Tanaka T, Tsutsui H, Yoshimoto T, Kotani M, et al. (2001). Interleukin-18 is elevated in the sera from patients with atopic dermatitis and from atopic dermatitis model mice, NC/Nga. Int. Arch. Allergy Immunol. 125: 236-240. http://dx.doi. org $/ 10.1159 / 000053821$

Tone M, Thompson SA, Tone Y, Fairchild PJ, et al. (1997). Regulation of IL-18 (IFN-gamma-inducing factor) gene expression. J. Immunol. 159: 6156-6163.

Verhaeghe B, Gevaert P, Holtappels G, Lukat KF, et al. (2002). Up-regulation of IL-18 in allergic rhinitis. Allergy 57: 825830. http://dx.doi.org/10.1034/j.1398-9995.2002.23539.x

Wei P, Kou W, Zhang C, Kang H, et al. (2016). Genetic variations in interleukin-12B in allergic rhinitis. Immunol. Res. 64: 329-336. http://dx.doi.org/10.1007/s12026-015-8758-6

Wigginton JE, Cutler DJ and Abecasis GR (2005). A note on exact tests of Hardy-Weinberg equilibrium. Am. J. Hum. Genet. 76: 887-893. http://dx.doi.org/10.1086/429864

Wong CK, Ho CY, Ko FW, Chan CH, et al. (2001). Proinflammatory cytokines (IL-17, IL-6, IL-18 and IL-12) and Th cytokines (IFN-gamma, IL-4, IL-10 and IL-13) in patients with allergic asthma. Clin. Exp. Immunol. 125: 177-183. http://dx.doi.org/10.1046/j.1365-2249.2001.01602.x

Yoshizawa Y, Nomaguchi H, Izaki S and Kitamura K (2002). Serum cytokine levels in atopic dermatitis. Clin. Exp. Dermatol. 27: 225-229. http://dx.doi.org/10.1046/j.1365-2230.2002.00987.x

Zhao N, Liu HJ, Sun YY and Li YZ (2016). Role of interleukin-6 polymorphisms in the development of allergic rhinitis. Genet. Mol. Res. 15: 1-6.

Genetics and Molecular Research 16 (3): gmr16039641 